\title{
PENINGKATAN KREATIVITAS PENGELOLAAN UNSUR-UNSUR GERAK TARI DI ACEH BESAR
}

\author{
Sabri Gusmail ${ }^{1}$, Prasika Dewi Nugra², Fitra Airiansyah ${ }^{3}$ \\ Prodi Seni Tari, Jurusan Seni Pertunjukan \\ Institut Seni Budaya Indonesia (ISBI) Aceh, Indonesia. \\ e-mail: sabri.gusmail86@gmail.com,prasikadewinugra@gmail.com, fitraariol@gmail.com
}

Diterima : 17 April 2019. Disetujui : 9 Mei 2019. Dipublikasikan : 30 Juni 2019

(O2019 - DESKOVI Universitas Maarif Hasyim Latif. Ini adalah artikel dengan akses terbuka di bawah lisensi CC BY 4.0 (https://creativecommons.org/licenses/by/4.0/)

\begin{abstract}
ABSTRAK
Artikel ini adalah bagian dari hasil penelitian terkait proses kreatif koreografi di Aceh Besar. Diperlukan pengetahuan secara teori dan praktik mendasar untuk pengelolaan gerak sebagai media ungkap tari. Penelitian yang dilakukan di Aceh Besar membahas permasalahan daya kreativitas mencipta motif gerak dalam kajian koreografi garap bentuk. Jenis penelitian adalah penelitian kualititif dengan menggunakan metode penelitian tindakan (action research). Mengidentifkasi masalah khusus dan menentukan tindakan sebagai solusi masalah tersebut. Tahapan penelitian antara lain : perencanaan (planning), pelaksanaan (acting), pemantauan (monitoring atau observing), pelatihan terpadu dan penilaian (reflecting atau evaluating). Tindakan dilaksanakan dalam bentuk pelatihan pengelolaan unsur-unsur gerak tari, kajian koreografi garap bentuk. Menjalin kegiatan kemitraan dengan Bidang Kebudayaan, Dinas Pendidikan dan Kebudayaan Aceh Besar untuk melaksanakannya. Menggabungkan 2 (dua) teknik dalam pelaksanaan pelatihan, yaitu : penyampaian materi secara teori dan mendemonstrasikan secara praktik. Penelitian ini diharapkan dapat berkontribusi untuk meningkatan kreativitas dalam pengelolaan gerak sebagai substansi dasar tari bagi para pelaku seni tingkat SMP, SMA/SMK maupun komunitas seni di Aceh Besar. Kedepannya peserta pelatihan diharapkan mampu menghasilkan karya-karya seni inovatif dalam peningkatan perkembangan seni tari di Aceh.
\end{abstract}

Kata kunci: Koreografi, proses kreatif, pelatihan, pengelolaan gerak tari.

\begin{abstract}
This article is part of the results of research related to the creative process of choreography in Aceh Besar. Knowledge is needed in theory and fundamental practice for the management of motion as a medium for expressing dance. Research conducted in Aceh Besar discusses the issue of the power of creativity to create motion motives in the study of choreography in terms of form. This type of research is qualitative research using action research methods. Identify specific problems and determine actions as a solution to the problem. Stages of research include: planning, implementation (acting), monitoring or observing, integrated training and assessment (reflecting or evaluating). The action was carried out in the form of training in the management of the elements of dance movement, the study of choreography in the form. Establish a partnership with the Culture field of Aceh Besar Education and Culture Office to implement it. Combining 2 (two) techniques in the implementation of the training, namely: delivering material theoretically and demonstrating in practice. This research is expected to contribute to increasing creativity in the management of motion as the basic substance of dance for junior and senior high school / vocational arts practitioners and the arts community in Aceh Besar. In the future the training participants are expected to be able to produce innovative works of art in improving the development of dance in Aceh.
\end{abstract}

Keywords: Choreography, creative process, training, management of dance movements.

\section{PENDAHULUAN}

Fungsi seni tari sangat erat kaitannya terhadap pelaku, penikmat seni dan masyarakat pendukungnya. Sebagai pelaku seni seseorang berhak mengapresiasikan imajinasinya dalam berbagai aspek, baik sebagai luapan emosi pribadi, spiritual ataupun ritual, hubungan kemasyarakatan, pendidikan dan lain sebagainya. Penikmat seni atau penonton dapat memperoleh apresiasi dan ilmu dari berbagai pertunjukan seni yang telah disajikan, terlepas dari bagaimana kemampuan si penonton dapat menafsirkan karya seni yang telah disajikan. Masyarakat pendukung seni tersebut juga sangat berperan penting dalam mempertahankan, memelihara dan melestarikan sebuah seni yang telah dimiliki sebagai aset budaya bangsa sehingga keberadaannya tetap terjaga. Seni pertunjukan bertujuan untuk menyajikan atau mempertunjukan 
sebuah karya seni pertunjukan kepada masyarakat atau to present arts work (dance, drama, music) before an audience. (Hadi, 2012:3).

Produk seni pada saat ini telah mengalami perkembangan pesat pada beberapa sektor, antara lain : bentuk penyajian, tujuan dan fungsi produk seni tersebut diciptkan. Disisi lain pengaruh globalisasi dan era canggih dalam pemanfaatan teknologi juga menjadi unsur pendukung bagaimana produk seni tersebut dapat diapresiasi, dipublikasi dan diperdagangkan sebagai kebutuhan profit. Sehingga dalam perkembangannya, menciptakan karya seni membutuhkan perhatian khusus untuk menghasilkan karya yang berkwalitas sesuai dengan kebutuhan dan fungsi karya tersebut diciptakan.

Meninjau perkembangan penciptaan karya tari di Aceh Besar yang dihasilkan sebagai bentuk ekspresi dalam pencaharian kemapanan dalam berkarya dan perwujudan identitas. Maka koreografer harus mampu meningkatkan daya kreativitas mencipta. Sebagaimana tari dijadikan sebagai luapan ekspresi koreografer dalam kesatuan rangkaian gerak dan diterjemahkan oleh penari sebagai refleksi pemikiran koreografer. Sehingga secara kebentukan, karya tari dapat mewakili karakter dan identitas koreografer. Selain menghadirkan estetik gerak, jika dipahami secara spesifik karya tari adalah salah satu pernyataan budaya. Sehingga sifat, gaya dan fungsi sebuah tari selalu tidak dapat dilepaskan dari kebudayaan yang menghasilkannya. Perbedaan sifat dan ragam tari dalam berbagai kebudayaan ini bisa disebabkan oleh banyak hal, seperti : lingkungan alam, perkembangan sejarah, sarana komunikasi dan temperamen manusianya, yang semua itu akan membentuk suatu citra kebudayaan yang khas. Hidup dan tumbuhnya tari sangat erat kaitannya dengan citra masing-masing kebudayaan itu. (Sedyawati dkk, 1986:3).

Perkembangan seni tari di Aceh Besar menjadi bagian dalam pengamatan penulis, terutama produk seni yang dihasilkan. Berdasarkan pengamatan yang dilakukan dan hasil diskusi dengan beberapa komunitas serta seniman tari yang terdapat di Aceh Besar dan Banda Aceh, tercatat bahwa pola mencipta gerak dalam karya tari yang sering diciptakan cenderung masih berorientasi meminjam pola gerak tari tradisi sebagai motif gerak yang digunakan. Akibatnya banyak ungkapan yang mempertanyakan tingkat kreativitas si koreografer. Pada dasarnya karya tari lahir dari sebuah perwujudan gagasan dan ide seorang koreografer dan terdapat unsur kreativitas didalamnya. Sehingga seorang koreografer hendaknya selalu melakukan penjelajahan dan pencarian kreativitas secara berkesinambungan, baik itu ide gagasan maupun wujud karya. Senada dengan apa yang disampaikan Novelis Perancis Malraux dalam buku Alma M. Hawkins "Creating Through Dance", bahwa berkreasi berarti melihat, menjadikan dan mengerjakan. Menurut dia, seorang pencipta memberikan dunia pengalamannya, mengambil posisi dan mengontrol dari apa yang ia lihat dan menjadikannya sesuatu yang dijadikan (reduction) dan merubah bentuk (metamorphosis) yang hasilnya suatu kesatuan yang utuh dan unik (Hawkins, 1988 :11). Untuk itu proses kreatif sangat diperlukan oleh koreografer. Proses kreatif biasanya meliputi tangkapan indrawi, perasaan tentang apa yang sedang dirasakan, eksplorasi terhadap pengamatan dan perasaan, koneksi hubungan imaji antar pengalaman empirik (sekarang dan yang tersimpan), tindakan dalam pengolahan kesatuan seluruh elemen dalam membentuk produk seni. Kenyataan yang sering terjadi, membicarakan kreativitas tidaklah semudah mengaplikasikannya dalam proses mencipta. Banyak koreografer yang frustasi dalam mencari kreativitas tersebut. Hal ini menjadi wajar jika dikaitkan dengan daya imaji personal pencipta dalam mewujudkan sebuah karya.

Proses kerja koreografi di Aceh Besar yang mengenyampingkan kreativitas dapat berdampak negatif pada hasil karya dan keabsahan orisinalitas karya yang diciptakan. Permasalahan lain yang akan hadir jika proses kerja tersebut dilakukan terusmenerus adalah tidak tampaknya perbedaan antar karya yang diciptakan, sehingga semua karya akan terlihat sama dan tidak memperlihatkan karakteristik personal. Walaupun setiap individu memiliki tingkatan dan cara yang berbeda-beda dalam meningkatkan daya kreativitas. Dalam berkarya perlu diasah dengan capaian respons kreatif, seperti melakukan proses eksplorasi dan improvisasi, serta melalui proses koreografi dengan berbagai permasalahannya yang memberikan satu kesempatan bagi koreografer maupun penari untuk berfikir, merasakan, mengimajinasikan, serta mencipta. (Hawkins, 1988: 43). Dari penjelasan diatas diperlukan pola-pola kegiatan secara berkelanjutan. Sehingga untuk mencipta tari diperlukan respon kreatif pengelolaan gerak sebagai substansi utama tari dalam meningkatkan pengetahuan dan wawasan koreografi. Kreativitas tersebut dapat menggiring penikmat agar dapat membedakan antara tari tradisi dengan tari kreasi yang diciptakan, sehingga menutup peluang musnahnya tari tradisi di Aceh, khususnya Aceh Besar seiring waktu berjalan.

Berdasarkan uraian diatas, maka diperlukan penelitian yang membahas tentang kreativitas dalam proses koreografi di Aceh Besar. Cara atau gaya mencipta motif gerak sebuah karya tari yang dianggap belum pernah diteliti oleh penulis sebelumnya terutama dalam kajian riset koreografi. Diharapkan penelitian ini dapat menemukan permasalahan utama dari minimnya kreativitas dalam mencipta motif gerak tari. Penelitian ini juga berupaya untuk memberikan solusi atas permasalahan tersebut dalam bentuk pelatihan yang melibatkan perwakilan sanggar atau komunitas tari, SMP, SMA dan SMK di Aceh Besar sebagai objek penelitian. Fokus penelitian ini adalah daya kreativitas mencipta motif gerak dari aspek pengelolaan unsurunsur gerak tari kajian koreografi garap bentuk. 


\section{METODE PENELITIAN}

Jenis penelitian ini adalah penelitian kualititif dengan menggunakan metode penelitian tindakan (action research). Penelitian tindakan merupakan pola atau metode dan kekuatan yang sering digunakan bagi para praktisi penelitian karena menuntut peneliti untuk terlibat dalam proses perbaikan atau perubahan prilaku. Metode ini dikembangkan yang memperbolehkan peneliti dan peserta bekerja sama untuk menganalisis sistem sosial dengan pandangan untuk mengubahnya (Moleong, 2014: 238). Sehingga responden penelitian tidak hanya diperankan sebagai objek tetapi juga dapat dijadikan sebagai subjek. Menggunakan pendekatan kolaboratif untuk menemukan permasalahan dengan memposisikan subjek penelitian setara dengan peneliti dan menjadi partisipan yang aktif selama proses penelitian serta berorientasi pada tindakan. Menekankan pada tujuan utama dari penelitian tindakan, yaitu meningkatkan (improve) dan melibatkan (involve). Untuk itu penelitian ini bertujuan meningkatkan kreativitas pengelolaan gerak dalam proses koreografi dan melibatkan praktisi tari di Aceh Besar.

Tahapan penelitian antara lain : 1) perencanaan (planning), 2) pelaksanaan (acting), meliputi koordinasi pelaksanaan tindakan dengan melibatkan mitra, pembagian kerja tim, pendataan peserta, persiapan data materi pelatihan, 3) pemantauan (monitoring atau observing), penyebaran materi pelatihan, monitoring ke masing-masing lokasi peserta, 4) pelatihan terpadu dan penilaian (reflecting atau evaluating).

\section{PEMBAHASAN}

Penelitian yang dilakukan bermuara pada tindakan untuk memberikan solusi dari permasalahan yang terjadi. Tindakan yang dirancang adalah pelatihan pengelolaan unsur-unsur gerak tari di Aceh Besar. Perencanaan penelitian dilakukan atas dasar pengamatan penciptaan tari di Aceh Besar, dalam hal ini melihat pementasan-pementasan tari pada acaraacara seni baik dalam bentuk pagelaran ataupun lomba tari. Kemudian merancang penelitian untuk menemukan permasalahan atau fokus penelitian untuk menemukan tindakan yang tepat untuk diaplikasikan sebagai solusi permasalahan. Berdasarkan kumpulan data, pengamatan dan wawancara, teridentifikasi bahwa terdapat keresahan atas penggarapan karyakarya tari yang dalam pelahirannya masih meminjam pola-pola gerak tari tradisi. Apalagi gerak-gerak tradisi hadir tanpa melalui pengembangan. Seperti yang disampaikan oleh Khairul Anwar seorang seniman dan praktisi tari Aceh "saat ini banyak sekali gerak-gerak tari tradisi dipakai dalam tari-tari kreasi dan gerak tersebut dipotong-potong, saya takut jika generasi kedepan salah tafsir tentang tari tradisinya sendiri". Senada dengan pernyataan tersebut melalui diskusi non formal, Jamal (pimpinan sanggar Senar Aceh Besar) menyampaikan bahwa keterbatasan pengetahuan dalam mengolah gerak mengakibatkan tari-tari yang dihasilkan oleh sanggarnya memiliki kemiripankemiripan motif gerak. Oleh karena itu fokus penelitian ini adalah daya kreativitas mencipta motif gerak dari aspek pengelolaan unsur-unsur gerak tari kajian koreografi garap bentuk. Sehingga tindakan yang dianggap tepat adalah melakukan pelatihan untuk membantu memecahkan solusi tersebut.

Pelaksanaan pelatihan dilakukan dengan menggabungkan 2 (dua) teknik yaitu penyampaian materi secara teori dan mendemonstrasikan secara praktik. Metode ini dipilih untuk lebih memudahkan penyampaian materi kepada peserta dan mempercepat rangsang kinestetik dalam pengolahan gerak tari. Peserta juga dibekali modul materi pelatihan yang dapat dibawa pulang sebagai bahan pengayaan bacaan dan pedoman kerja kreatif mencipta tari di masa yang akan datang.

Pendekatan pelatihan merujuk pada metode konstruksi mencipta tari dalam buku Jacqueline Smith, terjemahan Ben Suharto yang berjudul Komposisi Tari : Sebuah Petunjuk Praktis bagi Guru" dijelaskan bahwa metode konstruksi I atau proses awal komposisi tari terdiri atas rangsang tari, tipe tari, perlakuan terhadap bahan untuk membuat gerak tari representasional dan simbolik, improvisasi, seleksi pemula gerak tari (Smith, 1976:20). Oleh karena itu kedudukan gerak sebagai substansi utama tari menjadi penting untuk dikelola dengan baik.

Gerak menjadi ungkapan personal yang diekspresikan oleh tubuh dari hasil pengalaman mental dan emosional yang dilalui koreografer. Gerak-gerak yang ditarikan oleh penari merupakan sebuah prilaku tubuh yang dinamis, artinya pola-pola gerak yang dihasikan merupakan seluruh kesatuan rangkain gerak yang dihasilkan secara kontinyu dari awal hingga akhir pertunjukan. Bagi apresiator pertunjukan tari sesungguhnya menanggapi impulse dari para penari, lewat apa yang disebut dengan kesadaran kinestetik simpati (kinesthetic sympathy) (Martin, 1969:12). Impulse mengandung pemahaman movement dan motion, yaitu movement atau gerak yang dihasilkan dari pergerakan tubuh penari dan motion sebagai sebuah residu atau kesan yang ditangkap oleh penonton dari pergerakan tubuh penari di pentas. Sehingga dari pemahaman singkat movement dan motion diatas, dipahami bahwa gerak sebagai bahan baku sebuah koreografi tidaklah sama dengan gerak fisik yang dilakukan dalam kehidupan keseharian, tetapi gerak yang telah distilir atau didistorsi, artinya gerak-gerak yang telah mengalami perubahan bentuk, baik itu gerak-gerak yang bersifat murni maupun maknawi. (Hadi, 2014:12-13).

Tahapan pelaksanaan (acting), antara lain : koordinasi pelaksanaan tindakan dengan melibatkan mitra, pembagian kerja tim, pendataan peserta, persiapan data materi pelatihan, pemantauan (monitoring atau observing), penyebaran materi pelatihan, monitoring ke masing-masing lokasi peserta, 
pelatihan terpadu dan penilaian (reflecting atau evaluating).

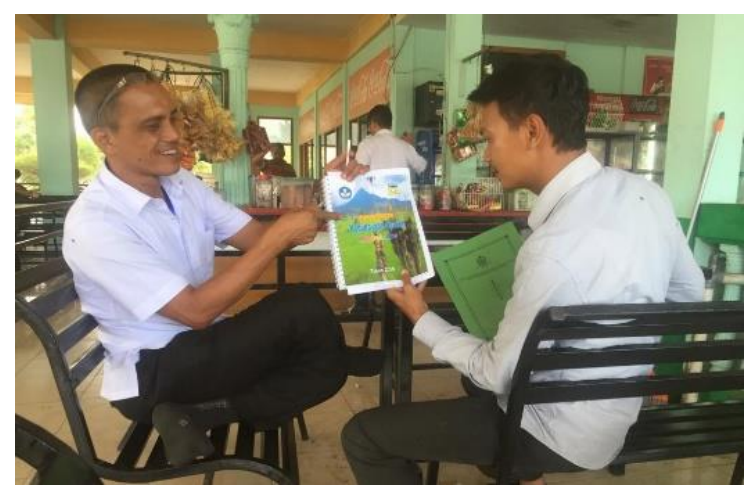

Gambar 1. Koordinasi tim dengan Kabid Kebudayaan

Dinas Pendidikan dan Kebudayaan Aceh Besar, sebagai mitra pelaksanaan pelatihan

(Dokumentasi : Muamar, 2018)

Peserta pelatihan yang terlibat dalam pelaksanaan tindakan tersebut adalah SMP Negeri 1 Kota Jantho, SMA Negeri 1 Kota Jantho, SMK 1 Kota Jantho, Sanggar Senar, Ariol Dance Teater dan Labor Seni Terasuluh. Materi pelatihan terfokus pada unsur gerak tari sebagai substansi utama karya tari, yaitu : ruang, waktu dan tenaga.. Kepekaan terhadap elemenelemen tersebut, pemilihan yang khas, serta pemikiran dan penyusunan yang didasarkan pada pertimbanganpertimbangan yang mendalam merupakan alasan utama kenapa tari dapat menjadi ekspresi seni (Widyastutieningrum, 2014:45).

1. Ruang

a. Garis (Kesan yang ditimbulkan dari gerak tubuh penari)

b. Volume (Jangkauan gerak yang dibuat oleh penari, tergantung dari besar kecilnya ruang gerak yang diiciptakan penari)

c. Level (Tinggi dan rendah posisi tubuh ketika melakukan gerak)

d. Fokus pandang (Konsentrasi penari ketika melakukan gerak)

e. Arah hadap (Pemilihan sudut tertentu dalam melakukan gerak)

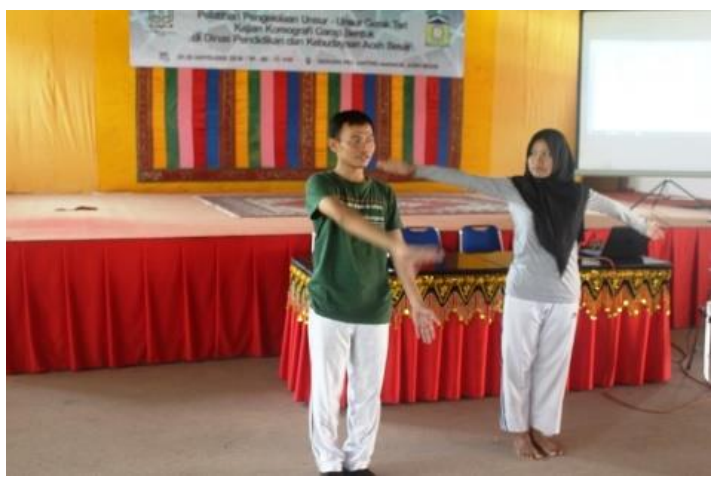

Gambar 2. Demonstrasi materi pelatihan ( pengelolaan ruang )

(Dokumentasi : Rolly Afriansyah, 2018)
2. Waktu

a. Tempo (Jangka waktu atau kecepatan tubuh dalam menyelesaikan sebuah rangkaian gerak)

b. Ritme (Pengaturan pola-pola gerak yang mengarah ke bentuk struktural seperti : awalan, perkembangan dan akhir)

c. Meter (Pengaturan jarak waktu diantara rangkaian gerak)

3. Tenaga

a. Intensitas (Berkaitan dengan tingkatan atau besaran tenaga yang digunakan, sehingga dapat menghasilkan tingkat ketegangan tertentu dalam sebuah tari)

b. Aksen/tekanan (Penggunaan tenaga yang tidak rata. Gerakan yang dilakukan secara tiba-tiba dan kontras. Aksen /tekanan biasanya dilakukan sebagai alat untuk mengenali dan membedakan pola-pola dan ritme-ritme gerak yang khas).

c. Kwalitas (Berkaitan dengan cara penggunaan dan penyaluran tenaga. Bagaimana mengawali gerakan, mengendalikannya dan mengakhiri gerakan).

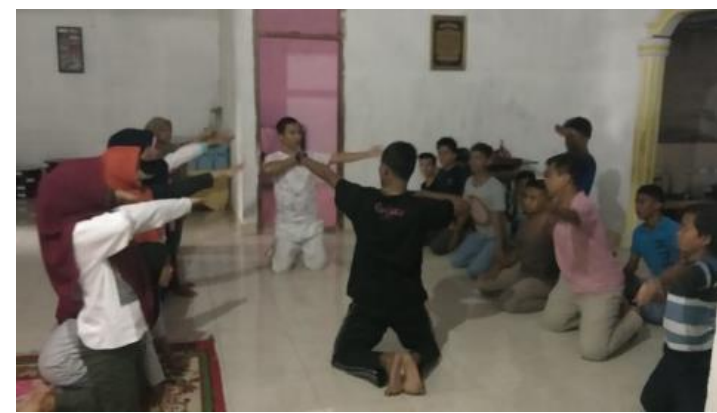

Gambar 3. Proses pengelolaan gerak di masingmasing komunitas/sanggar, sebelum pelatihan terpadu. Lokasi foto di sanggar Senar kota Jantho (Dokumentasi : Jamal, 2018)

Selain unsur-unsur gerak tari sebagai fokus pelatihan, di dalam modul materi pelatihan juga bahas secara singkat mengenai apa itu tari, defenisi tari menurut para ahli, desain keruangan estetik, sembilan elemen tari menurut La Meri dan jenis-jenis tari di Indonesia. Bahasan ini diharapkan menjadi bahan bacaan bagi peserta pelatihan dalam memperkaya pengetahuan di bidang ilmu tari. Sehingga dalam proses mencipta tari, pengalaman empirik dari rangsang kinestetik yaitu pelaksanaan pelatihan dan rangsang visual dari membaca modul materi pelatihan dapat menjadi bagian dalam proses kreatif menghasilkan koreografi yang baik. Walaupun untuk menghasilkan karya koreografi yang baik harus didukung oleh kemampuan tubuh yang siap pakai, diperlukan waktu yang cukup serta pencarian yang terus menerus agar tubuh dapat berbuat lebih banyak didalam koreografi (Sarjiwo, 2010:85). 


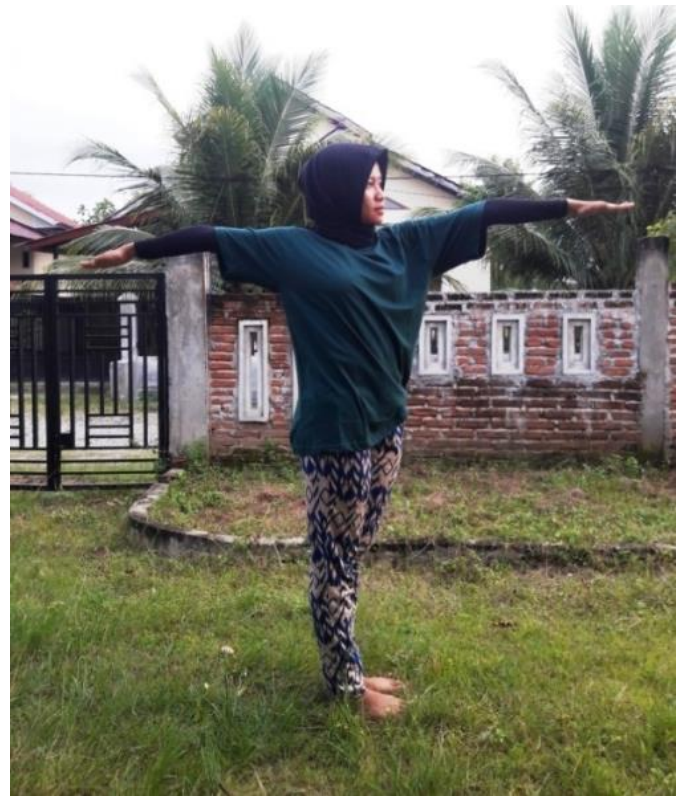

Gambar 4. Desain lurus (salah satu bentuk desain keruangan estetik) pada modul materi pelatihan, Peraga oleh Cut Sarah Novitri (Dokumentasi : Prasika Dewi Nugra, 2018)

\section{Pelatihan Terpadu}

Pelatihan terpadu dilakukan pada tanggal $29 \mathrm{~s} / \mathrm{d}$ 30 november 2018 di Aula Wisma PKK dengan menghadirkan seluruh peserta pelatihan. Kegiatan ini dilakukan selama 2 (dua) hari, dimulai dari pukul 09:00 s/d 17:00 WIB. Kegiatan pelatihan dibuka oleh ketua peneliti dan dilakukan selama 2 (dua) sesi pada setiap harinya. Sesi 1 dimulai pada pukul 10:00 s/d 12:30 WIB dan sesi 2 pada pukul 14:00 s/d 16:30 WIB.

Peserta pelatihan dikelompokan dalam group kecil untuk saling berbagi kinerja dan pengalaman untuk pengelolaan unsur-unsur gerak. Eksplorasi dan improvisasi pencarian gerak berpijak pada pola-pola gerak tradisi Aceh, hingga akhirnya akan tercipta motif gerak baru. Menjadikan pola gerak tradisi sebagai pijakan gerak dianggap menjadi sebuah titik tolak atau sumber ide dasar bagi seorang koreografer dalam pengelolaan gerak tari. Kepekaan yang kuat untuk memahami dan mencermati lingkungan sekitar menjadi bagian terpenting bagi koreografer untuk mengaplikasikan pemikiran ke dalam sebuah karya tari. Tanpa adanya sebuah pondasi yang kuat mustahil sebuah konstruksi yang ingin dihasilkan dapat berdiri kokoh dan bertahan. Kedudukan tradisi lokal berada pada posisi yang sangat sentral dalam proses perwujudan kreativitas seni, jika dipahami secara seksama. Apabila gerak sebagai substansi utama telah diolah dengan baik, maka tidak tertutup kemungkinan dalam menerjemahkan konsep ke sebuah karya dibutuhkan pengolahan elemen lain, seperti : properti tari. Properti dapat dijadikan unsur penguat dalam keutuhan karya tari, apabila terdapat keterbatasan bagi gerak untuk menyampaikan pesan dalam bentuk komunikasi visual (gusmail, $2018: 24$ ).

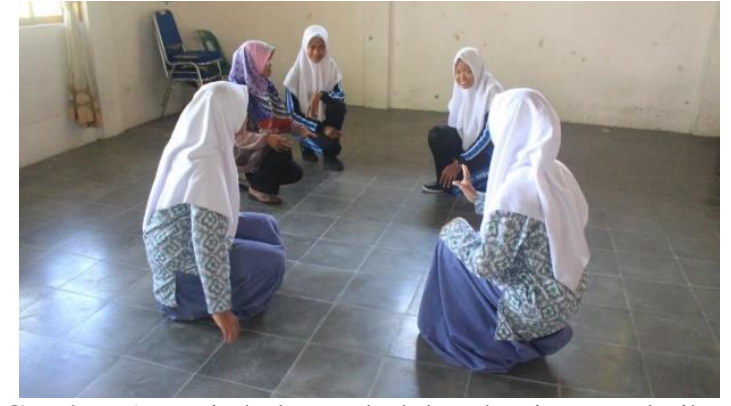

Gambar 5. Kerja kelompok dalam kegiatan Pelatihan (Dokumentasi : Rolly Afriansyah, 2018)

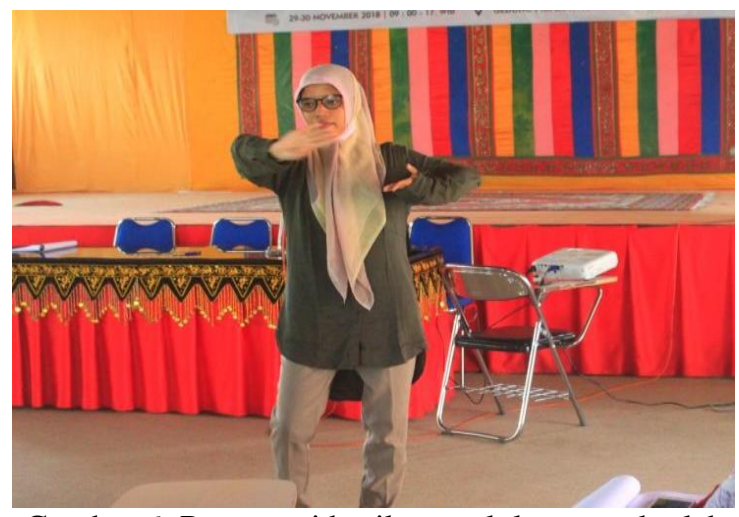

Gambar 6. Presentasi hasil pengelolaan gerak oleh salah satu peserta pelatihan

(Dokumentasi : Rolly Afriansyah, 2018)

\section{KESIMPULAN}

Penelitian tindakan (action research) yang dilakukan di banda Aceh melibatkan Dinas Pendidikan dan Kebudayaan Aceh Besar sebagai mitra pelatihan atas tindakan dari minimnya daya kreativitas mencipta motif gerak dalam aspek pengelolaan gerak tari di Aceh Besar. Pelaksanaan pelatihan Pengelolaan UnsurUnsur Gerak Tari, Kajian Koreografi garap Bentuk di Dinas Pendidikan dan Kebudayaan Aceh Besar diharapkan dapat membantu dalam peningkatan kreativitas pengelolaan Gerak sebagai substansi dasar tari bagi para pelaku seni tingkat SMP, SMA/SMK maupun komunitas seni di Aceh Besar. Sinergi antar institusi diharapkan mampu berperan aktif dalam menindaklanjuti UU RI. No 5. Tahun 2017, tentang Pemajuan Kebudayaan dan menjawab salah satu permasalahan atas kondisi yang terjadi di masingmasing sekolah ataupun komunitas seni di Aceh Besar, yaitu minimnya wawasan dan pengetahuan dalam pengolahan gerak sebagai medium utama tari. Disisi lain pelatihan ini juga menjadi usaha peningkatan kreativitas dengan menjadikan pola-pola gerak tradisi sebagai pijakan pengelolaan gerak untuk menghasilkan pola gerak baru dalam mencipta sebuah tari. Semoga penelitian ini dapat bermanfaat dan memperoleh hasil yang baik untuk peningkatan keilmuan tari di Aceh Besar secara berkesinambungan. 


\section{UCAPAN TERIMA KASIH}

1. Terima kasih kepada LPPMPMP ISBI Aceh sebagai penyelenggara pelaksanaan penelitian dan pengabdian kepada masyarakat ISBI Aceh tahun 2018.

2. Bidang Kebudayaan Dinas Pendidikan dan Kebudayaan Aceh Besar sebagai mitra pelatihan Peningkatan Kreativitas Pengelolaan Unsur-Unsur Gerak Tari di Aceh Besar

3. Seluruh peserta pelatihan, narasumber dan informan

\section{DAFTAR PUSTAKA}

Gusmail, Sabri. 2018, April. Properti Tari Waktu Dalam Lipatan : Analisis Semiotika Melalui Pendekatan Charles Sanders Peirce. Jurnal Puitika : 14 (1), 14-25.

Hadi, Y. Sumandiyo. 2012. Seni Pertunjukan dan Masyarakat Penonton, Yogyakarta : BP ISI Yogyakarta

Hadi, Y. Sumandiyo, 2014. Koreografi (BentukTeknik-Isi). Yogyakarta : Cipta Media.

Hawkins, Alma M. 1988. Creating Through Dance (Revised Edition). Disadur oleh Y. Sumandiyo
Hadi. 2003. Mencipta Lewat Tari. Yogyakarta : Manthili.

Martin, John. 1969. The Modern Dance. New York : Dance Horizon Incorporated.

Moleong, Lexy J. 2014. Metodologi Penelitian Kualitatif Edisi Revisi. Bandung : PT. Remaja Rosdakarya.

Sarjiwo. 2010, Juni. Teknik Pengelolaan Tenaga : Kajian Dalam Koreografi Garap Tunggal. Resital : 11(1), 81-91. Retrieved April 16, 2017, from

http://journal.isi.ac.id/index.php/resital/article/v iewFile/501/95.

Sedyawati, Edi, dkk. 1986. Pengetahuan Elemen Tari dan Beberapa Masalah Tari. Jakarta : Direktorat Kesenian Proyek Pengembangan Kesenian Jakarta.

Smith, Jaqualine. 1976. Dance Composition : A Pratical Guide for Teacher. Terjemahan Ben Suharto. 1985. Komposisi Tari, Sebuah Pertunjukan Praktis Bagi Guru. Yogyakarta : Ikalasti.

Widyastutieningrum, Sri Rochana dan Dwi Wahyudiarto. 2014. Pengantar Koreografi. Surakarta : ISI Press Surakarta. 